Tropical Journal of Pharmaceutical Research April 2020; 19 (4): 837-843

ISSN: $1596-5996$ (print); 1596-9827 (electronic)

(C) Pharmacotherapy Group, Faculty of Pharmacy, University of Benin, Benin City, 300001 Nigeria.

\title{
Essential oil from Chenopodium ambrosioides L. induces mitochondrial-mediated pathway and endoplasmic reticulum stress-related apoptosis in human liver cancer SMMC-7721 cells
}

\author{
Qian Rui-Hua1, Zhu Xiao-Huan ${ }^{1}$, Hao Jun-Mei ${ }^{1}$, Li Hai-Ying ${ }^{1}$, Song Bo-Han', Ren \\ Qiu-Rong ${ }^{1}$, Ma Dan-Wei ${ }^{1}$, Wang Ya-Nan ${ }^{1 *}$, Chen Zhao-Bin ${ }^{2,3}$ \\ ${ }^{1}$ College of Life Science, Sichuan Normal University, Chengdu 610101, ${ }^{2}$ Department of Public Health Laboratory Sciences, \\ West China School of Public Health, Sichuan University, Chengdu 610041, ${ }^{3}$ Shenzhen Nanshan Center for Disease Control \\ and Prevention, Shenzhen 518054, PR China
}

*For correspondence: Email: 273218760@qq.com; Tel: +86 (28) 84480655

\begin{abstract}
Purpose: To evaluate the cytotoxic effect of essential oil derived from Chenopodium ambrosioides $L$. in Sichuan Province on human liver cancer SMMC-7721 cells, as well as its possible molecular mechanisms.

Methods: Cytotoxicity was characterized by MTT assay and transmission electron microscopy (TEM) of SMMC-7721 cells ultrastructure. The apoptotic effect of the essential oil was evaluated by changes in mitochondrial membrane potential and Western blot assay.

Results: MTT assay data indicate that the essential oil was cytotoxic to SMMC-7721 cells, while TEN revealed that there were vacuoles and nucleus fragmentation in the SMMC-7721 cell cytosol, cell swelling, and a large amount of leakage. Mitochondrial membrane potential assay and Western Blot data indicate that the essential oil induced cell apoptosis.

Conclusion: The essential oil of Chenopodium ambrosioides L. in Sichuan Province seems to induce apoptosis of human liver cancer SMMC-7721 cells via the mitochondrial-mediated pathway and endoplasmic reticulum stress. Thus, this plant requires further investigation as a potential source of an anti-liver cancer drug.
\end{abstract}

Keywords: Chenopodium ambrosioides Essential oil; Anti-tumor activity, Liver cancer Apoptosis, SMMC-7721 cells

\begin{abstract}
This is an Open Access article that uses a fund-ing model which does not charge readers or their institutions for access and distributed under the terms of the Creative Commons Attribution License (http://creativecommons.org/licenses/by/4.0) and the Budapest Open Access Initiative (http://www.budapestopenaccessinitiative.org/read), which permit unrestricted use, distribution, and reproduction in any medium, provided the original work is properly credited.

Tropical Journal of Pharmaceutical Research is indexed by Science Citation Index (SciSearch), Scopus, International Pharmaceutical Abstract, Chemical Abstracts, Embase, Index Copernicus, EBSCO, African Index Medicus, JournalSeek, Journal Citation Reports/Science Edition, Directory of Open Access Journals (DOAJ), African Journal Online, Bioline International, Open-J-Gate and Pharmacy Abstracts
\end{abstract}

\section{INTRODUCTION}

Traditional medicinal plants are natural sources of bioactive compounds, which can be used as food additives, and are used as ingredients in functional foods and nutritional products in health promotion [1]. Chenopodium ambrosioides L. is an annual or perennial fragrant herb belonging to the Chenopodiaceae [2]. Its common names include fairy grass, red zeeland, and smelly 
Chenopodium [3]. It is native to tropical America and is now widely distributed across temperate, subtropical, and tropical countries [3]. The extracts of roots, leaves and anthotaxis of C. ambrosioides have been used by the local people as dietary flavorings and as Chinese medicines for hundreds of years [4].

C. ambrosioides has anti-rheumatic, insecticidal, and analgesic effects [5]. It is commonly used in the treatment of skin rheumatism, skin eczema, dysmenorrhea, amenorrhea, snake bites, and other diseases [5]. Currently, C. ambrosioides is known for its anti-molluscocidal, anti-fungal, antiinfection, anti-oxidation, and anti-tumor effects [3]. At present, it has been reported that whether the C. ambrosioides essential oil and flavanoids are cytotoxic to SMMC-7721 cells [6] and MCF-7 cells and ultimately induce apoptosis in such cells [7]. However, the mechanism for this cytotoxicity remains unclear.

Apoptosis usually occurs in multicellular organisms. The process is split into the internal pathway and the external pathway [8]. The internal pathway is also known as the mitochondrial apoptotic pathway, and many studies have shown that when this pathway is activated, cell survival depends largely on the functional status of the mitochondria [9]. The external pathway is in charge of surveying the conditions of the extracellular and intracellular environments to indicate whether the cell should survive or die $[10,11]$. The function of the endoplasmic reticulum (ER) is to fold and embellish proteins during the synthesis of proteins [12].

ER pressure is the outcome of various internal and external pressures, and it causes apoptosis when all attempts to adapt to stress fail [13]. Previous studies have shown that two main components of the essential oil under study, 1isopropyl-4-methylbenzene and a-terpinene, are not as good as essential oil in their anticancer activity [14]. Therefore, this study, further explores the molecular mechanism of apoptosis induced by the essential oil of $C$. ambrosioides in SMMC-7721 cells.

\section{EXPERIMENTAL}

\section{Materials}

C. ambrosioides plants were gathered from the street of Jingju Temple, Chengdu, Sichuan in September 2016 and confirmed as $C$. ambrosioides by Dr. Ma Danwei, College of Life Science, Sichuan Normal University, China. It is now stored in the Cell Biology Laboratory of the
College of Life Sciences, Sichuan Normal University.

\section{Preparation of extract of C. ambrosioides essential oil}

The gathered plants were shade-dried in a cool place. The $C$. ambrosioides essential oil was obtained by steam distillation [15], then dried (anhydrous sodium sulfate) and filtered (0.22 $\mu \mathrm{m}$ membrane). Finally, the extracted oil was stored in a brown agentia bottle sealed at $-20^{\circ} \mathrm{C}$.

\section{Cell culture}

SMMC-7721 cells were provided by the State Key Laboratory of Sichuan University and cultured in RPMI-1640 medium supplemented with fetal bovine serum and antibiotics. Cells were grown and kept at the $37{ }^{\circ} \mathrm{C}$ incubator aerated with $5 \% \mathrm{CO}_{2}$.

\section{Evaluation of cytotoxicity}

SMMC-7721 cells $\left(1 \times 10^{5}\right.$ cells $/ \mathrm{mL}, 100$ $\mu \mathrm{L} /$ hole) were inoculated in a 96 -orifice plate for $20 \mathrm{~h}$ in moist air at $37{ }^{\circ} \mathrm{C}$ and $5 \% \mathrm{CO}_{2}$. Then, the cells were attached to the tablet and treated with C. ambrosioides essential oil using 5 concentrations $(6.25,12.5,25,50$, and 100 $\mu \mathrm{g} / \mathrm{mL}$ ). $1 \%$ dimethyl sulphoxide (DMSO) treated cells as the negative control group, and 80 $\mu \mathrm{g} / \mathrm{mL}$ fluorouracil treated cells as the positive control group. After treatment at 24,48 , and $72 \mathrm{~h}$ with essential oil, $20 \mu \mathrm{L}$ MTT $(5 \mathrm{mg} / \mathrm{mL})$ was added to the culture solution and incubated for 4 $\mathrm{h}$. Then, the culture-medium was removed and $150 \mu \mathrm{L}$ DMSO was added to each pore. After 10 min of oscillation, absorbance $(A)$ was measured at $490 \mathrm{~nm}$. All experiments were conducted in triplicate. Cell viability (V) was calculated as in Eq 1.

$\mathrm{V}(\%)-(\mathrm{Ae} / \mathrm{Ad}) 100$

where $\mathrm{Ae}$ and $\mathrm{Ad}$ are the absorbance of essential oil- and DMSO-treated cells, respectively.

\section{Assessment of apoptosis via AO/EB staining}

Single-layer SMMC-7721 cells were incubated in the presence and absence of the essential oil derived from $C$. ambrosioides at various concentrations. After $24 \mathrm{~h}$, the cell suspension was mixed with the $A O / E B$ solution (Both $A O$ and EB are $100 \mu \mathrm{g} / \mathrm{mL})$. When viewed with a fluorescence microscope, living cells with $A O / E B$ staining were green, necrotic cells were red, 
early apoptotic cells were green, and late apoptotic cells were red.

\section{Examination of cell ultrastructure transmission electron microscopy (TEM)}

SMMC-7721 cells $\left(1.5 \times 10^{5}\right.$ cells $\left./ \mathrm{mL}\right)$ were inoculated in six-orifice plates. After $20 \mathrm{~h}$ of incubation, the cells were transferred into in $4 \mathrm{~mL}$ fresh RPMI-1640 culture-medium containing $C$. ambrosioides essential oil of $100 \mu \mathrm{g} / \mathrm{mL}$. The negative control group cells contained $1 \%$ DMSO. The cells were incubated at $37^{\circ} \mathrm{C}$, in $5 \%$ $\mathrm{CO}_{2}$ for $24 \mathrm{~h}$.

The treated cells were pre-fixed in electron microscopy fixative at $4^{\circ} \mathrm{C}$ for $2 \mathrm{~h}$, washed with PBS for $20 \mathrm{~min}$, treated with $1 \%$ osmium tetroxide at $4{ }^{\circ} \mathrm{C}$ for $1 \mathrm{~h}$, dewatered with a gradient set of ethanol and buried in epon. The ultra-thin slices were double dyed with saturated acetic acid solution and lead acetate, and Tecnai transmission electron microscope (Most Technology Development Co. Ltd, Beijing) was used to observe the cells using $200 \mathrm{kV}$ [16].

\section{Assessment of mitochondrial membrane potential}

SMMC-7721 cells $\left(3 \times 10^{5} / \mathrm{mL}\right)$ were grown in six-orifice plates, then with increasing concentration of essential oil (12.5, 50, 100 $\mu \mathrm{g} / \mathrm{mL}$ ) and processed, as above. The negative control had $1 \%$ DMSO, while the mitochondrial electron transport chain inhibitor carbonylcyanide-p-chlorophenyl hydrazone (CCCP) served as the positive control. After incubation at $37{ }^{\circ} \mathrm{C}$ in $5 \% \mathrm{CO}_{2}$ for $24 \mathrm{~h}$, the treated cells were washed with PBS and stained with $\quad 1 \quad \mathrm{mg} / \mathrm{mL}$ tetraethylbenzimidazolylcarbocyanine iodide (JC-1, Biyun days) dye was used for half an hour at $37{ }^{\circ} \mathrm{C}$ in the darkness [17]. The reduction of cell mitochondrial depolarization was detected, as shown by the transformation from red fluorescence to green fluorescence, and imaged under inverted fluorescent microscope [18].

\section{Western blot assay}

The essential oil derived from $C$. ambrosioides $(12.5,50,100 \mu \mathrm{g} / \mathrm{mL})$ or carrier-treated cells were lysed on ice in the presence of a complete protease inhibitor mixture in RIPA buffer and centrifuged at $12,000 \mathrm{rpm}$ for $10 \mathrm{~min}$. Bicinchoninic acid (BCA) protein assay kit (KGP903 Kaiji, Biological Company, Nanjing) was used to determine protein concentration. The same amount of protein specimens $(100 \mu \mathrm{g})$ were electrophoresed on SDS-polyacrylamide gel, then blotted onto the PVDF membrane (Hybond company, USA).

PVDF membrane was incubated for $1 \mathrm{~h}$ in $5 \%$ skimmed milk powder at $4{ }^{\circ} \mathrm{C}$, overnight with antibodies to: Cytochrome c (dilution 1:2000, ab133504), Bax (dilution 1:2000, ab32503), Bcl2 (dilution1:200, ab32124), Caspase 3 (dilution1:200, ab44976), Caspase 9 (dilution1:200, ab69514), Caspase 12 (dilution $1: 500$, ab62484), $\beta$-actin (dilution1:5000), and rabbit polyclonal anti-actin (all the antibodies were purchased from Abcam Abbott (Shanghai) Trading Co., Ltd., USA). After washing with PBST, the PVDF membranes were incubated in anti-rabbit $\lg G(\mathrm{H}+\mathrm{L})$ of goat with biotin (dilution1:5000, ab6721) and biotinylated antimouse $\lg G(H+L)$ in goats (dilution 1:5000, ab6789) secondary antibodies (Abcam Abbott Trading Co., Ltd., USA) for $2-3 \mathrm{~h}$ at room temperature.

Finally, after three $10 \mathrm{~min}$ of washing, immunoreactive signals were detected using an ECL detection system. These membranes were then exposed at various time points to ensure the best density. The relative protein levels were checked using $\beta$-actin as an internal standard. The experiments were repeated 3 times.

\section{Statistical analysis}

SPSS 17.0 (SPSS Inc, USA) was used for data analyses. Significant difference was analyzed by least significant difference ( $L S D)$ test, and $p<$ 0.05 was deemed statistically significant. Correlation was analyzed via bivariate method. All data are presented as mean \pm standard deviation (SD). Data were plotted using Microsoft Excel 2003 (Microsoft, USA).

\section{RESULTS}

\section{Cytotoxic activity against SMMC-7721 cancer cells}

Figure 1 shows the cytotoxic effects of $C$. ambrosioides essential oil on SMMC-7721 cell line. Time- and concentration-dependent inhibition were observed at 24,48 and $72 \mathrm{~h}$ with $\mathrm{IC}_{50} 26.28,12.50$ and $7.49 \mu \mathrm{g} / \mathrm{mL}$ respectively. During the $24 \mathrm{~h}$ period of treatment, the cell viability percentage values at 6.25 and 12.5 $\mu \mathrm{g} / \mathrm{mL}$ concentrations of the essential oil reduced cell viability to 94 and $72 \%$, respectively compared with the control. They were further reduced to 43,32 and $16 \%$ at concentrations of of 25,50 , and $100 \mu \mathrm{g} / \mathrm{mL}$, respectively. 


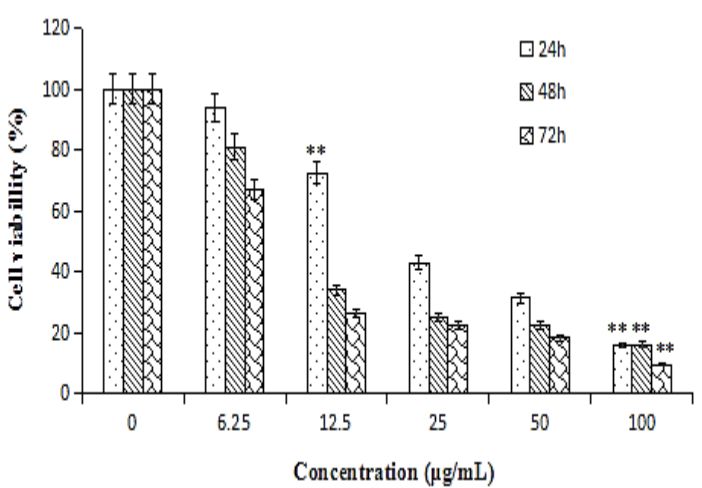

Figure 1: Cell viability between the SMMC-7721 cancer cell and the sample concentration was evaluated by MTT assay to evaluate the cytotoxic potential of essential oil compared with fluorouracil; the data are expressed as mean \pm SEM $(\mathrm{n}=3) ;{ }^{*} p<$ $0.05,{ }^{* *} p<0.001$ compared to control group (1\% DMSO)

\section{Effect of C. ambrosioides essential oil on} apoptosis of SMMC-7721 cells

Figure 2 shows the apoptosis of SMMC-7721 cells caused by $24 \mathrm{~h}$ of $\mathrm{C}$. ambrosioides essential oil treated at concentrations of $12.5,50$, and $100 \mu \mathrm{g} / \mathrm{mL}$. With increase of essential oil concentration, the number of late apoptotic cells increased. This indicates that the essential oil can lead to apoptosis of SMMC-7721 cells.
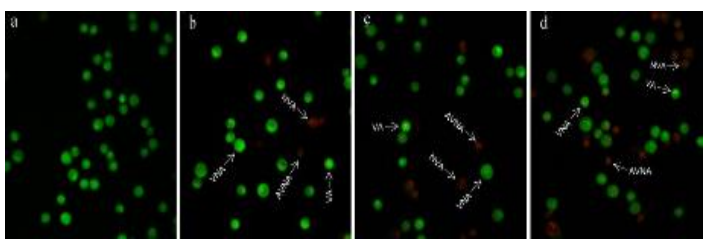

Figure 2: Morphological features of $C$. ambrosioides essential oil-treated SMMC-7721 cells via AO/EB double staining. $1 \%$ DMSO (a), $12.5 \mu \mathrm{g} / \mathrm{mL}$ (b), 50 $\mu \mathrm{g} / \mathrm{mL}$ (c), and $100 \mu \mathrm{g} / \mathrm{mL}$ (d) essential oil VNA indicates viable non-apoptotic cells; VA indicates the early apoptotic cells; NVA indicates late apoptotic cells; NVNA indicates necrotic cells

\section{Effect of C. ambrosioides essential oil on ultrastructure of SMMC-7721 cells}

The electron microscopy results showed that chromatin were distributed along the nuclear membrane in the SMMC-7721 cells treated with $100 \mu \mathrm{g} / \mathrm{mL}$ essential oil for $24 \mathrm{~h}$ contrasted with that of untreated control cells (Figure 3a). They also showed swollen mitochondria that had become spherical-shaped, a ruptured mitochondria ridge, a faded matrix, and vacuoles of various sizes in the cytoplasm (Figure 3b).

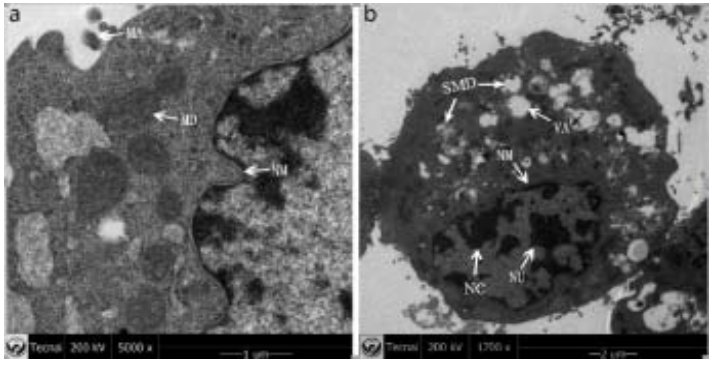

Figure 3: Effect of C. ambrosioides essential oil on ultrastructure of SMMC-7721 cells. After $24 \mathrm{~h}$ of treatment with $1 \%$ DMSO (a) and $100 \mu \mathrm{g} / \mathrm{mL}$ essential oil (b), the ultrastructure of SMMC-7721 cells was observed by transmission electron microscopy. CM indicates cell membrane; MA indicates microvilli; NM indicates nuclear membrane; NU indicates nucleoli; MD indicates mitochondria; VA indicates empty bubble; SMD indicates swelling mitochondria; NC indicates nuclear chromatin

\section{Effect of essential oil on mitochondrial membrane potential in SMMC-7721 cells}

From the supplementary photo taken with inverted fluorescence microscope (Figure 4), it is evident that the decrease of the mitochondrial depolarization in the cells exposed to essential oil and the transition from red to green fluorescence, is different in intensity in a concentration- dependent manner.
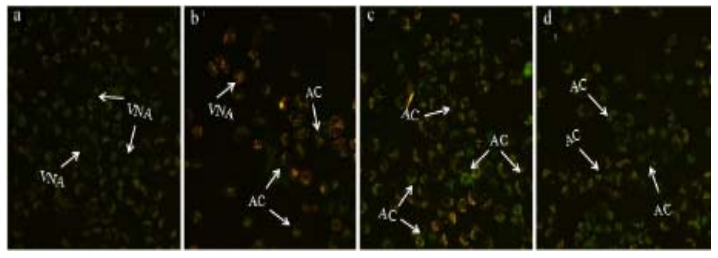

Figure 4: Effect of $C$. ambrosioides essential oil on mitochondrial membrane potential in SMMC-7721 cells. $1 \%$ DMSO (a), $12.5 \mu \mathrm{g} / \mathrm{mL}$ essential oil (b), 50 $\mu \mathrm{g} / \mathrm{mL}$ essential oil (c), $100 \mu \mathrm{g} / \mathrm{mL}$ essential oil (d) were treated for $24 \mathrm{~h}$, to induce apoptosis in the SMMC-7721 cells. VNA indicates viable non-apoptotic cells; AC indicates apoptotic cells

\section{Effect of the essential oil on expression of apoptosis-associated proteins}

Mitochondria mediated the role of mitochondrial pathway in essential oil induced apoptosis by studying the release of mitochondrial Cytochrome $\mathrm{C}$ into the cytoplasm, the consequent increase of Caspase- 9 and Caspase- 3 activity, and the mitochondrial apoptotic balance of protein Bax and antiapoptotic protein Bcl-2. As shown in Figure 5, along with the increase of essential oil, the activities of Caspase-9, Caspase-3, and Caspase-12 gradually increased as well. The 
western imprinting analysis also revealed that Cytochrome $\mathrm{C}$ released by mitochondria from SMMC-7721 cells increased after exposure to essential oil. This is because Cytochrome C activities Caspase- 9 thereby triggering a cascade of apoptotic cells, activation of Caspase-3 which promotes apoptosis [8]. We also examined the activities of $\mathrm{Bax}$ and $\mathrm{Bcl}-2$ by western blot analysis. This western blot analysis revealed that after essential oil administration the activity of proapoptotic Bax was raised, while the activity of $\mathrm{Bcl}-2$ protein reduced.

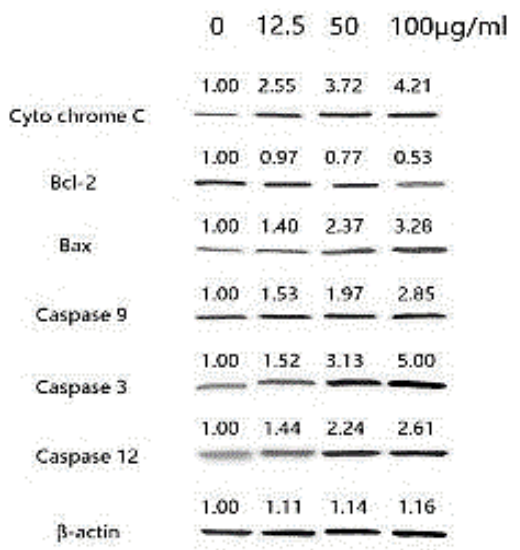

Figure 5: Western blot data for cytochrome C, Bcl-2, Bax, Caspase 9, Caspase 3, and Caspase-12 in SMMC-7721 cells treated with different concentration of $C$. ambrosioides essential oil for $24 \mathrm{~h}$; $\beta$-actin was used as an internal control

\section{DISCUSSION}

Natural plant products serve a vital function in the treatment of many diseases, and they are continually being studied to identify novel therapeutic agents [17]. Liver cancer is among the most common pernicious tumors in China. Liver cancer cells are not sensitive to chemotherapy and are prone to drug resistance, and because conventional chemotherapy drugs damage normal cells, the treatment of hepatocellular carcinoma is difficult $[18,19]$. Apoptosis is controlled by genetic material, and cells follow their own pathway to voluntarily undergo the death process [20].

Many studies have shown that the activation of apoptotic pathway by natural products in cancer cells can serve as a main protective mechanism to the occurrence development and progression of cancer [21,22]. In this study, the results of AO/EB staining showed that the nuclei of SMMC7721 cells exposed to $C$. ambrosioides essential oil exhibited nuclear condensation and fragmented chromatin typical of apoptosis in a dose-dependent manner. The change of MMP is a significant characteristic of apoptosis [23]. JC-1 staining demonstrated that the essential oil resulted in the decrease of MMP in SMMC-7721 cells. Under transmission electron microscopy, swollen mitochondria appeared in SMMC-7721 cells treated with the essential oil. These outcomes indicate that essential oil-induced apoptosis originated from to the mitochondria (Figure 6).

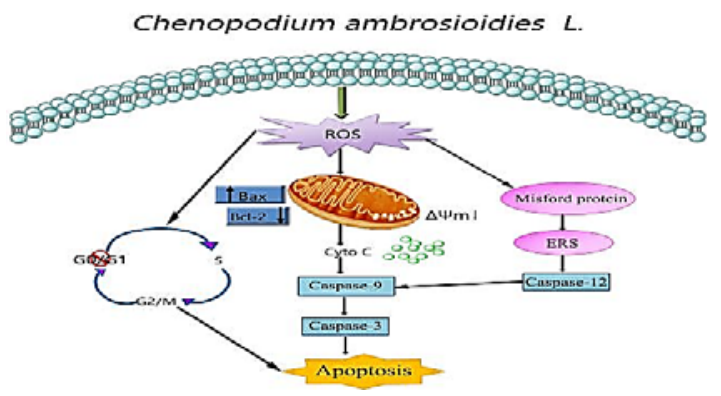

Figure 6: The mechanism of Chenopodium ambrosioides L. essential oil inducing apoptosis in an SMMC-7721 cell

Previous research had shown that $C$. ambrosioides essential oil induced apoptosis was caspase-dependent using the caspase inhibitor Z-VAD-FMK in SMMC-7721 cells, and that the essential oil also caused $\mathrm{G}_{0} / \mathrm{G}_{1}$ phase arrest, inducing SMMC-7721 cell death [6]. The essential oil and its main components, $\alpha-$ terpinene and 1-isopropyl-4-methylbenzene, can induce ROS production, interfere with antioxidant activity, and cause oxidative damage [23]. In this study, the activities of Cytochrome C, Caspase9, Caspase-3, and proapoptotic Bax increased and that of $\mathrm{Bcl}-2$ decreased in SMMC-7721 cells treated with the essential oil. Thus, the essential oil induces ROS generation, which promotes MMP loss, and this leads to $\mathrm{Bcl}-2$ and the expression of Bax levels to change, and then releases Cytochrome $\mathrm{C}$, which activates Caspase-9 and Caspase-3 to induce SMMC7721 cell apoptosis (Figure 6).

Endoplasmic reticulum stress is a physiological response that is part of a cell's resistance to adverse stimuli, but prolonged endoplasmic reticulum stress will activate Caspase-12 and then activate Caspase- 9 and Caspase- 3 cascade reactions, inducing apoptosis [24]. In this study, as the concentration of essential oil increased, the expression level of Caspase-12 protein increased in SMMC-7721 cells. This suggests that apoptosis induced by the essential oil in SMMC-7721 cells could also be through the endoplasmic reticulum stress pathway (Figure 6). The specific mechanism requires further study. 


\section{CONCLUSION}

The findings of this work show that the cytotoxic activity of Chenopodium ambrosioides L. essential oil against human hepatocellular carcinoma SMMC-7721 cell line is pronounced and that it induces apoptosis via mitochondrialmediated and endoplasmic reticulum stress pathways. Thus, the essential is capable of being developed into a drug for the treatment of liver cancer.

\section{DECLARATIONS}

\section{Acknowledgement}

This work was funded by National Natural Science Foundation of China (no. 31370549) and Key Inoculation Project of Sichuan Provincial Education Office (no. 16ZA0056).

\section{Conflict of interest}

No conflict of interest is associated with this work.

\section{Contribution of authors}

We declare that this work was done by the authors named in this article and all liabilities pertaining to claims relating to the content of this article will be borne by the authors.

\section{Open Access}

This is an Open Access article that uses a funding model which does not charge readers or their institutions for access and distributed under the terms of the Creative Commons Attribution License (http://creativecommons.org/licenses/by/ 4.0) and the Budapest Open Access Initiative (http://www.budapestopenaccessinitiative.org/rea d), which permit unrestricted use, distribution, and reproduction in any medium, provided the original work is properly credited.

\section{REFERENCES}

1. Skerget $M$, Kotnik $P$, Hadolin $M$, Hras $A R$, Simonic $M$, Knez Z. Phenols, proanthocyanidins, flavones and flavonols in some plant materials and their antioxidant activities. Food Chem 2005; 89(2): 191-198.

2. Hu WJ, Ma DW, Wang YN, Zhang H, Li Q. Allelopathic potential of the essential oil from Chenopodium ambrosioides L. on root tip cells of Vicia faba. Acta Ecol. Sin. 2011; 31(13): 3684-3690.

3. Nie $X N$, Liang ZS, Duan QM. GC fingerprinting of the essential oil from Chenopodium ambrosioides $L$. in
Different Areas. Acta Bot. Boreali-Occident. Sin. 2010; 30(11): 2334-2339.

4. Kliks MM. Studies on the traditional herbal anthelmintic Chenopodium ambrosioides L.: ethnopharmacological evaluation and clinical field trials. Soc Sci Med 1985; 21(8): 879-886.

5. De FV, Senatore F. Medicinal plants and phytotherapy in the amalfitan coast, salerno province, campania, southern italy. J Ethnopharmacol 1993; 39(1): 39-51.

6. Wang YN, Zhu XH, Ma DW, Du RY, Li DR, Ma DW. The Chenopodium ambrosioides $L$. essential oil induces caspase-dependent apoptosis in human liver cancer SMMC-7721 cells. Chinese Chung Yao Ts'ai 2016; 39(5): 1124-1128.

7. Wu JL, Ma DW, Wang YN, Zhang H, He B, Li Q, Zou ZY, Feng J. Cytotoxicity of essential oil of Chenopodium ambrosioides L. against human breast cancer MCF-7 cells. Trop J Pharm Res 2013; 12(6): 929-933.

8. Yang $H H$, Zhang $C$, Lai SH, Zeng CC, Liu YJ, Wang XZ. Isoliquiritigenin induces cytotoxicity in pc-12 cells in vitro. Appl Biochem Biotech 2017; 1-18.

9. Li J, Mcquade T, Siemer AB, Napetschnig J, Moriwaki K, Hsiao YS, Damko E, Moquin DM, Walz TM, McDermott $A E$, Chan FKM, Wu $H$. The rip1/rip3 necrosome forms a functional amyloid signaling complex required for programmed necrosis. Cell 2012; 150(2): 339-50.

10. Fulda S, Debatin KM. Signaling through death receptors in cancer therapy. Curr Opin Pharmacal 2004; 4: 327. 332.

11. Debatin KM, Krammer $P H$. Death receptors in chemotherapy and cancer. Oncogene 2004; 23: 29502966.

12. Walter $P$, Ron $D$. The unfolded protein response: From stress pathway to homeostatic regulation. Science 2011; 334(6059): 1081-1086.

13. Yamasaki S, Yagishita N, Nishioka K, Nakajima T. The roles of synoviolin in crosstalk between endoplasmic reticulum stress-induced apoptosis and p53 pathway. Cell Cycle 2007; 6(11): 1319-1323.

14. Wang YN, Wu JL, Ma DW, Li J, Zhang DY. Anticancer effects of Chenopodium ambrosiodes $L$. essential oil on human breast cancer MCF-7 cells in vitro. Trop J Pharm Res 2015; 14(10): 1813-1820.

15. Meng QH, Huang HJ, Liu Y, Liu XG, Wei SH, Zhang CX. Chemical compositions and allelopathic potential of volatile oil from Sorghum halepense (L.) Pers. Acta Phytophy Sin 2009; 36(3): 277-282.

16. Zhang CM. Study on molecular mechanism of HepG2 cytotoxicity and apoptosis induced by quinocetone. Beijing: J. China Agric. Univ. 2014.

17. Rahman MA, Akhtar J, Sahabjada, Arshad M. Evaluation of cytotoxic potential and apoptotic effect of a methanolic extract of bauhinia racemosa, lam. against a human cancer cell line, hela. Eur J Integr Med 2016; 8(4): 513-518.

18. $\mathrm{Li} X L$, Zhang $Y Z$. Xinyi volatile oil anti-allergy experimental study. Chin. J. Hosp. Pharm. 2002; 22(9). 520-523.

Trop J Pharm Res, April 2020; 19(4):842 
19. Zhang ZJ, Liu XL, Li HZ, Liu PP, Zhang X. Research progress on extraction methods of plant volatile oil and its application. J. Chin. Cereals Oils Assoc. 2011; 4: 118-122.

20. Cragg GM, Boyd MR, Khanna R, Newman DJ, Sausville EA. Natural products in drug discovery and development. J Nat Prod 1997; 60(1): 52-60.

21. Yuan L, Wei SP, Wang J, Liu XB. Isoorientin induces apoptosis and autophagy simultaneously by reactive oxygen species (ROS)-related p53, PI3K/Akt, JNK, and p38 signaling pathways in HepG2 cancer cells. J AGR Food Chem 2014; 62: 5390-5400.
22. Song $W$, Yang $H B$, Chen $P$, Wang $S M$, Zhao $L P, X u W H$, Fan HF, Gu X, Chen LY. Apoptosis of human gastric carcinoma SGC-7901 induced by deoxycholic acid via the mitochondrial-dependent pathway. Appl Biochem Biotech 2013; 171: 1061-1071.

23. Wang YN, Yang J, Zhu XH, Ren QR, Zhang $H$. Effect ofd-terpinene and 1-isopropyl-4-methylbenzene on oxidative damage induced by volatile oil from Chenopodium ambrosioides L. Southwest China J. Agric. Sci. 2016; 29(6): 1302-1306.

24. Wu J, Xu JY, Han SF, Qin LQ. Effects of genistein on apoptosis in HCT-116 human colon cancer cells and its mechanism. J. Hyg. Res. 2014; 43(1): 1-5. 